\title{
Effect of orientation and density of hydroxide precursor films on performance of dye-sensitized $\mathrm{ZnO}$ solar cells
}

\author{
Hisasuke KAJIHARA, Manabu HAGIWARA and Shinobu FUJIHARA ${ }^{\dagger}$
}

Department of Applied Chemistry, Keio University, Yokohama 223-8522, Japan

\begin{abstract}
Layered hydroxide zinc carbonate (LHZC) films were fabricated on glass substrates through a chemical bath deposition method using aqueous solutions. The films had morphologies where sheet-like LHZA particles were accumulated more or less vertically to the substrate surface. Changes in the concentration of a zinc source and the increasing rate of $\mathrm{pH}$ had a remarkable effect on the $b$-axis orientation and the film density of the LHZC films. The morphologies of the LHZC films were maintained after their conversion to $\mathrm{ZnO}$ by thermal treatments. The increase in the film density resulted in the improvement of the open-circuit voltage and the fill factor of dye-sensitized solar cells using N719-loaded $\mathrm{ZnO}$ films as photoanodes. The light-to-electricity conversion efficiency of $3.49 \%$ was obtained in the DSSC using the present $\mathrm{ZnO}$ film.
\end{abstract}

(O2016 The Ceramic Society of Japan. All rights reserved.

Key-words : Layered hydroxide zinc carbonate, Zinc oxide, Chemical bath deposition, Dye-sensitized solar cells

[Received January 25, 2016; Accepted April 12, 2016]

\section{Introduction}

The semiconductor material used for photoanodes in dyesensitized solar cells (DSSCs) should necessarily have a wide band gap and a flat band potential that is more positive than the excited state potential of the dye molecule. Zinc oxide $(\mathrm{ZnO})$, a common n-type semiconductor material, meets these requirements and its higher electron mobility $\left(10^{2} \mathrm{~cm}^{2} \mathrm{~V}^{-1} \mathrm{~s}^{-1}\right)$ is a clear advantage over other materials.

The morphology of the $\mathrm{ZnO}$ material is regarded as one of the most important factors influencing the DSSC performance. Therefore, a large number of researches have been reported so far to investigate the relationship between the $\mathrm{ZnO}$ morphology and the DSSC performance. ${ }^{2-5}$ ) The method of preparing the $\mathrm{ZnO}$ material is also an important focus of controlling the morphology. We have reported the fabrication of $\mathrm{ZnO}$ films via layered basic zinc salts (LBZSs) and also the performance of DSSCs using them as photoanodes. ${ }^{6)-8)}$ Such the films generally consist of mesoporous nanosheets, which offer large surface areas favorable for the effective dye adsorption.

Layered hydroxide zinc acetate [LHZA; $\mathrm{Zn}_{5}\left(\mathrm{CH}_{3} \mathrm{COO}\right)_{2}(\mathrm{OH})_{8}$. $\left.2 \mathrm{H}_{2} \mathrm{O}\right],{ }^{6}$ nitrate $\left[\mathrm{LHZN} ; \mathrm{Zn}_{5}\left(\mathrm{NO}_{3}\right)_{2}(\mathrm{OH})_{8} \cdot 2 \mathrm{H}_{2} \mathrm{O}\right],{ }^{7}$ and carbonate [LHZC; $\left.\mathrm{Zn}_{4} \mathrm{CO}_{3}(\mathrm{OH})_{6} \cdot \mathrm{H}_{2} \mathrm{O}\right]^{8)}$ were actually prepared as precursor films through a chemical bath deposition (CBD) method and converted into $\mathrm{ZnO}$ by thermal treatments. Especially, the LHZCderived $\mathrm{ZnO}$ film showed a relatively high short-circuit current density $\left(13.8 \mathrm{~mA} \mathrm{~cm}^{-2}\right)$ in spite of a considerably small film thickness of $4 \mu \mathrm{m} .{ }^{8)}$ This was partly attributed to the fact that the dense morphology of the LHZC film was maintained after its conversion to $\mathrm{ZnO}$, working well to adsorb a large amount of dyes.

When fabricating the LBZS films, water can be used as a solvent exclusively for LHZC and alcohol is necessary for other LBZSs. The CBD method with aqueous solutions is beneficial

\footnotetext{
$\dagger$ Corresponding author: S. Fujihara; E-mail: shinobu@applc.keio. ac.jp

* Preface for this article: Dol http://dx.doi.org/10.2109/jcersj2.124.P6-1
}

without using expensive or toxic organic chemicals. Furthermore, chemical reactions can be controlled by $\mathrm{pH}$ (or $\left[\mathrm{OH}^{-}\right]$) and concentrations of metal ions for the film formation through heterogeneous nucleation and subsequent crystal growth. Generally, the predominance of heterogeneous or homogeneous nucleation is determined according to the position in the solubility diagram for the film-forming species dissolved in the aqueous solution. ${ }^{9)}$ It is also known that the level of supersaturation strongly influences the crystal morphology. ${ }^{10)}$

In the present report, we attempted to increase the film density for improving the solar-cell performance parameters: the opencircuit voltage $\left(V_{\mathrm{OC}}\right)$, the short-circuit current density $\left(J_{\mathrm{SC}}\right)$, and the fill factor $(f f)$. An increased frequency of heterogeneous nucleation was expected to increase the density of LHZC precursor films in concentration-controlled CBD processes. Our results then demonstrated that the $\mathrm{ZnO}$ films from the LHZC films with the increased density had higher $V_{\mathrm{OC}}$ and $f f$ values when applied to DSSCs. On the other hand, $J_{\mathrm{SC}}$ was slightly decreased probably because of the aggregation of adsorbed dyes or the retarded diffusion of liquid electrolytes in the denser photoanode.

\section{Experimental procedure}

\subsection{Fabrication of $\mathrm{LHZC}$ and $\mathrm{ZnO}$ films}

Zinc nitrate hexahydrate $\left[\mathrm{Zn}\left(\mathrm{NO}_{3}\right)_{2} \cdot 6 \mathrm{H}_{2} \mathrm{O}, 99 \%\right.$, Wako Pure Chemical Industries] and urea (99.0\%, Wako) were dissolved in deionized water, followed by an ultrasonic treatment. Concentrations of $\mathrm{Zn}\left(\mathrm{NO}_{3}\right)_{2} \cdot 6 \mathrm{H}_{2} \mathrm{O}$ and urea were first fixed at 0.05 and $1.0 \mathrm{M}$ (defined as standard concentrations), respectively. A pH value of the resultant solution (initially $\mathrm{pH} \approx 6$ ) was adjusted to 4 by adding diluted nitric acid $(50 \mathrm{mM})$ under stirring to be used as the CBD solution. Borosilicate slide glass (S1111, Matsunami Glass) or fluorine-doped tin oxide-coated glass (FTO glass, Nippon Sheet Glass) was used as substrates for the deposition of LHZC films. The thickness and the sheet resistance of the FTO layer were $780 \mathrm{~nm}$ and $9.20 \Omega \mathrm{sq}^{-1}$, respectively, as directly measured in the present study. All of the glass substrates were cleaned beforehand by sonicating in a dilute $\mathrm{NaOH}$ aqueous solution, in deionized water and finally in high-purity acetone. The substrate 
Table 1. The concentrations and the deposition time used for the CBD method

\begin{tabular}{cccc}
\hline Film & {$\left[\mathrm{Zn}\left(\mathrm{NO}_{3}\right)_{2} \cdot 6 \mathrm{H}_{2} \mathrm{O}\right] / \mathrm{M}$} & {$[\mathrm{urea}] / \mathrm{M}$} & Time $/ \mathrm{h}$ \\
\hline Film-S & 0.05 & 1.0 & 6 \\
Film-0.5x & 0.025 & 1.0 & 6 \\
Film-0.75x & 0.0375 & 1.0 & 6 \\
Film-1.25x & 0.0625 & 1.0 & 6 \\
Film-1.5x & 0.075 & 1.0 & 6 \\
Film-2.0x & 0.100 & 1.0 & 6 \\
Film-1.5x' & 0.075 & 1.5 & 6 \\
Film-2.0x' & 0.100 & 2.0 & 6 \\
Film-3.0x' & 0.150 & 3.0 & 6 \\
Film-4.0x' & 0.200 & 4.0 & 6 \\
Film-3.0x & \\
Film-4.0x & & 3.0 & 4 \\
\hline
\end{tabular}

was then immersed in $17 \mathrm{~mL}$ of the CBD solution placed in a glass bottle $\left(18 \mathrm{~mL}\right.$ in volume) and kept still at $80^{\circ} \mathrm{C}$ for $6 \mathrm{~h}$ in a constant-temperature chamber (ST-110, Espec). After $6 \mathrm{~h}$, the substrate was removed from the solution and the film deposited on the substrate was rinsed with deionized water and dried at room temperature. The film, which was deposited on the substrate surface facing down during the immersion, was used in the present work. On the surface facing up, the film was barely formed but was removed completely by scratching off.

Next, in one set of experiments, only the initial $\mathrm{Zn}\left(\mathrm{NO}_{3}\right)_{2}$. $6 \mathrm{H}_{2} \mathrm{O}$ concentration (corresponding to $\left[\mathrm{Zn}^{2+}\right]$ ) was varied by 0.5 to 2.0 times the standard concentration $(0.05 \mathrm{M})$. The films fabricated in each concentration are labeled Film- $0.5 x, 0.75 x, S$, $1.25 \mathrm{x}, 1.5 \mathrm{x}$, and $2.0 \mathrm{x}$ (Film-S is obtained from the standard concentrations). In the other set of experiments, both the $\mathrm{Zn}\left(\mathrm{NO}_{3}\right)_{2}$ $6 \mathrm{H}_{2} \mathrm{O}$ and the urea concentration were further varied simultaneously from 1.5 to 4 times the standard concentrations, keeping the ratio of the initial concentrations constant ([urea $] /\left[\mathrm{Zn}^{2+}\right]=$ 20). The films thus fabricated are labeled Film-1.5 $x^{\prime}, 2.0 x^{\prime}, 3.0 x^{\prime}$, and $4.0 x^{\prime}$. Due to the detachment of Film-3.0x and $4.0 x^{\prime}$, the immersing time was attempted to be reduced to $4 \mathrm{~h}$ for these films (labeled Film-3.0x $\mathrm{x}^{\prime \prime}$ and $4.0 \mathrm{x}^{\prime \prime}$ ). The concentrations and the deposition time are summarized in Table 1 together with the film labeling.

All of the above-obtained precursor LHZC films were finally heated at $400^{\circ} \mathrm{C}$ for $10 \mathrm{~min}$ in air using a muffle furnace in order to be converted into $\mathrm{ZnO}$.

\subsection{Characterization}

The crystal structure of the films was identified by X-ray diffraction (XRD) analysis using a Bruker model AXS D8-02 diffractometer. The X-ray source was $\mathrm{CuK} \alpha$ radiation for the measurement. Surface and cross-sectional morphologies of the films were observed by field emission scanning electron microscopy (FESEM) using an FEI model Sirion or Inspect S50.

\subsection{DSSC measurement}

The $\mathrm{ZnO}$ film was immersed in a $0.3 \mathrm{mM} \mathrm{RuL}_{2}(\mathrm{NCS})_{2}: 2 \mathrm{TBA}$ $\left(\mathrm{L}=2,2^{\prime}\right.$ bipyridyl-4,4'-dicarboxylic acid and TBA $=$ tetrabutylammonium; N719, Solaronix) ethanol solution at $60^{\circ} \mathrm{C}$ for 10 min under reflux. An $\mathrm{I}^{-} / \mathrm{I}_{3}{ }^{-}$redox couple electrolyte, which was composed of $0.1 \mathrm{M}$ LiI (97.0\%, Wako), $50 \mathrm{mM} \mathrm{I}_{2}$ (99\%, Kanto Chemical), $0.45 \mathrm{M}$ 1,2-dimethyl-3-propylimidazolium iodide (Kanto Chemical), 0.25 M 4-tert-butylpyridine (96\%, SigmaAldrich), and 3-methoxypropionitrile (99.0\%, Wako), was prepared separately. The ZnO/N719 electrode, the electrolyte, a
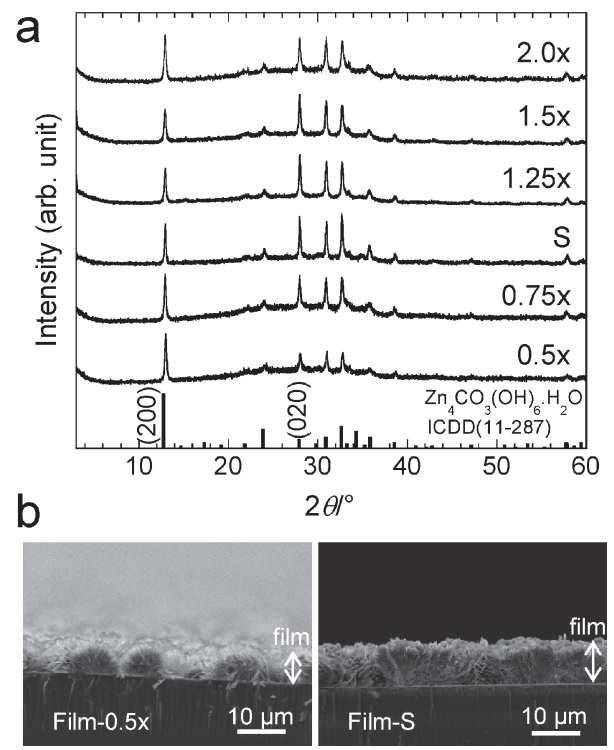

Fig. 1. (a) XRD patterns of Film- $0.5 \mathrm{x}, 0.75 \mathrm{x}, \mathrm{S}, 1.25 \mathrm{x}, 1.5 \mathrm{x}$, and $2.0 \mathrm{x}$ and (b) cross-sectional FESEM images of Film- $0.5 \mathrm{x}$ and $\mathrm{S}$ deposited on the slide glass substrates.

polyester spacer film ( $25 \mu \mathrm{m}$ in thickness), and a counter platinum electrode were set up to construct a sandwich-type open cell. The active area was fixed at $25 \mathrm{~mm}^{2}(5 \mathrm{~mm} \times 5 \mathrm{~mm})$ by a mask.

The cell parameters, $V_{\mathrm{OC}}, J_{\mathrm{SC}}, f f$, and the conversion efficiency $(\eta)$ were determined by photocurrent-photovoltage $(J-V)$ measurements. A 500-W Xe lamp (UXL-500SX, Ushio) was used for the light source. An AM 1.5 filter, a water filter, and an infrared cut filter (S76-HA50, Hoya) were placed in the light path to regulate the light in a wavelength range between 400 and $800 \mathrm{~nm}$. The $J-V$ curves were measured with a potentiostat (HSV-110, Hokuto Denko) under the simulated sunlight $\left(100 \mathrm{~mW} \mathrm{~cm}^{-2}\right)$. The amount of dyes adsorbed on the $\mathrm{ZnO}$ electrode was determined using an absorbance measurement by an ultra violetvisible-near infrared spectrophotometer (V-670, Jasco) with a preliminarily formed calibration curve. The dyes on the $\mathrm{ZnO}$ film were desorbed by immersing in $5 \mathrm{~mL}$ of a $0.5 \mathrm{M} \mathrm{NaOH}$ ethanol/ water $(\mathrm{v} / \mathrm{v}=1)$ solution and the absorbance was measured for the resultant dye solution.

\section{Results and discussion}

\subsection{Effect of $\mathrm{Zn}\left(\mathrm{NO}_{3}\right)_{2} \cdot 6 \mathrm{H}_{2} \mathrm{O}$ concentration}

Figure 1(a) shows XRD patterns of the films (Film-0.5x, $0.75 \mathrm{x}, \mathrm{S}, 1.25 \mathrm{x}, 1.5 \mathrm{x}$, and $2.0 \mathrm{x})$ deposited on the slide glass substrates from the solutions with various $\mathrm{Zn}\left(\mathrm{NO}_{3}\right)_{2} \cdot 6 \mathrm{H}_{2} \mathrm{O}$ concentrations. The respective patterns agree with the diffraction data of $\mathrm{Zn}_{4} \mathrm{CO}_{3}(\mathrm{OH})_{6} \cdot \mathrm{H}_{2} \mathrm{O}$ (ICDD 11-287) in terms of the peak position. However, the relative intensity of the peaks is largely different from that of the ICDD pattern, indicating that the deposited films have specific crystallographic orientation, as discussed below. Figure 1(b) compares cross-sectional FESEM images of the LHZC films (Film-0.5x and S) deposited on the slide glass substrates. The films as a whole have the morphology based on accumulation of the sheet-like LHZC particles. Generally the LBZS compounds tend to grow two dimensionally because of their layered structure. ${ }^{6-8)}$ The principal surface of the LHZC sheet corresponds to the $b-c$ plane and the crystal growth proceeds at the edges of this place in the direction outwards from the plane. It appears that the number of nuclei on the substrate depends on the $\mathrm{Zn}\left(\mathrm{NO}_{3}\right)_{2} \cdot 6 \mathrm{H}_{2} \mathrm{O}$ concentration. Actually Film- 


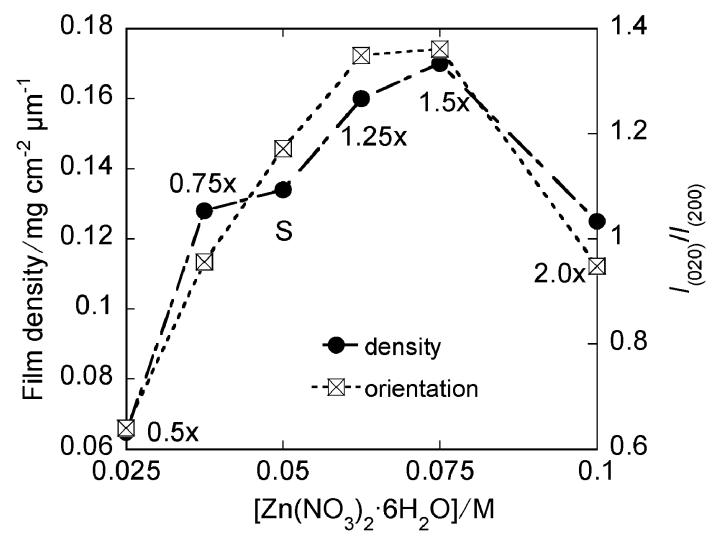

Fig. 2. The dependence of the film density and the degree of the $b$-axis orientation, expresses as $I_{(020)} / I_{(200)}$, on the $\mathrm{Zn}\left(\mathrm{NO}_{3}\right)_{2} \cdot 6 \mathrm{H}_{2} \mathrm{O}$ concentration of the CBD solution for Film- $0.5 x, 0.75 x, S, 1.25 x, 1.5 x$, and 2.0x. The slide glass substrates were used here.

$0.5 \mathrm{x}$ seems to have had a smaller number of nuclei at an initial stage of the deposition, judging from hemispherical accumulation of the LHZC particles grown from each nucleus. Such the accumulation structure is hardly observed in Film-S, thereby indicative of a larger number of nuclei formed on the substrate.

When the LHZC sheet is grown perpendicular to the substrate as observed for Film-S in Fig. 1(b), the $a$ - and $c$-axes of the LHZC crystal are parallel to the substrate surface while the $b$-axis comes to be perpendicular to the substrate surface. ${ }^{11)}$ Figure 2 shows the dependence of the film density and the degree of the $b$-axis orientation on the $\mathrm{Zn}\left(\mathrm{NO}_{3}\right)_{2} \cdot 6 \mathrm{H}_{2} \mathrm{O}$ concentration of the CBD solution. Here, the film density was determined as the weight of the film per unit area, further divided by the film thickness. The degree of the $b$-axis orientation was evaluated by calculating a $I_{(020)} / I_{(200)}$ peak intensity ratio. A good correlation is found between the film density and the $b$-axis orientation in Fig. 2. This correlation can be explained by the difference in the number of nuclei on the substrate. When there are a large number of nuclei on the substrate, a film consisting of densely packed sheet-like particles is expected to be formed. In such the condition, the initial growth of the sheet-like particles perpendicular to the substrate would be preferential because the growth of those parallel to the substrate might be blocked by the adjacent one. The nucleation of LHZC on the substrate (heterogeneous nucleation) is accelerated by increasing the $\mathrm{Zn}^{2+}$ concentration, which leads to the increase in the film density and the $b$-axis orientation, as seen from Film- $0.5 \mathrm{x}$ to $1.5 \mathrm{x}$ in Fig. 2.

The $\mathrm{pH}$ value (more significantly $\left[\mathrm{OH}^{-}\right]$in the present case) is also the important factor to discuss the film formation in the aqueous solution. Figure 3 shows the change of $\mathrm{pH}$ with the deposition time up to $60 \mathrm{~min}$, which was compared between the standard and double the $\mathrm{Zn}\left(\mathrm{NO}_{3}\right)_{2} \cdot 6 \mathrm{H}_{2} \mathrm{O}$ concentration. Interestingly, there is no noticeable difference in the $\mathrm{pH}$ values at any time among the concentration conditions. In each condition, the $\mathrm{pH}$ value rises from 4 due to the generation of $\mathrm{OH}^{-}$by the decomposition of urea ${ }^{12)}$ and reaches approximately 6 at $30 \mathrm{~min}$. After $30 \mathrm{~min}$, the $\mathrm{pH}$ value is kept nearly constant because of the consumption of $\mathrm{OH}^{-}$by the deposition of LHZC. When only urea is dissolved in water without adding $\mathrm{Zn}\left(\mathrm{NO}_{3}\right)_{2} \cdot 6 \mathrm{H}_{2} \mathrm{O}$, the $\mathrm{pH}$ value continues to increase rapidly, exceeding 6 within $15 \mathrm{~min}$. This fact suggests that the nucleation of LHZC could start before $15 \mathrm{~min}$ with the enough generation of $\mathrm{OH}^{-}$even at the higher $\mathrm{Zn}\left(\mathrm{NO}_{3}\right)_{2} \cdot 6 \mathrm{H}_{2} \mathrm{O}$ concentration. Then the film deposition

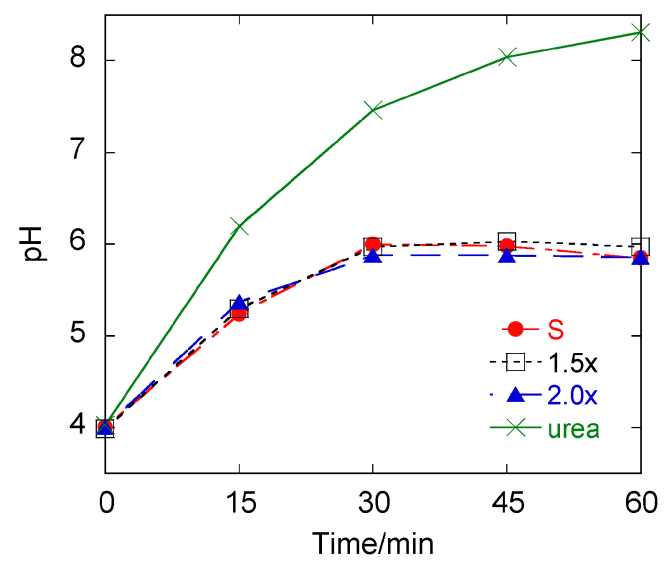

Fig. 3. The change of $\mathrm{pH}$ of the $\mathrm{CBD}$ solution with time for the standard to double the $\mathrm{Zn}\left(\mathrm{NO}_{3}\right)_{2} \cdot 6 \mathrm{H}_{2} \mathrm{O}$ concentration. The data for the urea solution are also shown.
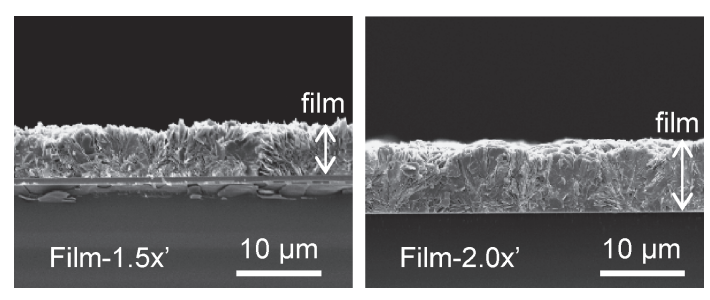

Fig. 4. Cross-sectional FESEM images of Film-1.5 $\mathrm{x}^{\prime}$ and 2.0 $\mathrm{x}^{\prime}$ deposited on the slide glass substrates.

was visibly confirmed at the time between 30 and $45 \mathrm{~min}$ for every concentration.

From Fig. 2, the films tend to have the stronger $b$-axis orientation and the higher density with increasing the $\mathrm{Zn}\left(\mathrm{NO}_{3}\right)_{2} \cdot 6 \mathrm{H}_{2} \mathrm{O}$ concentration. In Film-2.0x, however, the $b$-axis orientation and the density are considerably decreased from those of Film-1.5x. In the FESEM observation, Film-2.0x had a more porous hierarchical structure, as compared to Film-S, which might result from the excess $\left[\mathrm{Zn}^{2+}\right]$ concentration. The above results indicate that the morphology of LHZC is determined by the concentration ratio of $\mathrm{Zn}^{2+}$ and urea in the aqueous CBD solution. This agrees with the morphological change of LHZC reported in the literature. ${ }^{13)}$

\subsection{Effect of $\mathrm{Zn}\left(\mathrm{NO}_{3}\right)_{2} \cdot 6 \mathrm{H}_{2} \mathrm{O}$ and urea concentra- tion}

The deposition of the LHZC film was further examined by changing both the $\mathrm{Zn}\left(\mathrm{NO}_{3}\right)_{2} \cdot 6 \mathrm{H}_{2} \mathrm{O}$ and the urea concentration, keeping the ratio of the initial concentration constant ([urea]/ $\left.\left[\mathrm{Zn}^{2+}\right]=20\right)$. Figure 4 shows cross-sectional FESEM images of the resultant LHZC films (Film-1.5 $\mathrm{x}^{\prime}$ and 2.0 $\mathrm{x}^{\prime}$ ) deposited on the slide glass substrates. As compared to Film-S shown in Fig. 1(b), these films have more densely accumulated sheet-like LHZC particles with increasing the concentrations of the CBD solution. Figure 5 shows the dependence of the film density and the degree of the $b$-axis orientation on the $\mathrm{Zn}\left(\mathrm{NO}_{3}\right)_{2} \cdot 6 \mathrm{H}_{2} \mathrm{O}$ concentration for Film-1.5 $\mathrm{x}^{\prime}$ and $2.0 \mathrm{x}^{\prime}$. The density of Film-1.5x and 2.0x, which appeared in Fig. 2 with keeping the urea concentration constant, was also plotted for comparison. It is seen that the density of Film-1.5 $\mathrm{x}^{\prime}$ and $2.0 \mathrm{x}^{\prime}$ is actually higher than that of Film-S. Moreover, comparing at the same $\mathrm{Zn}\left(\mathrm{NO}_{3}\right)_{2} \cdot 6 \mathrm{H}_{2} \mathrm{O}$ concentration $(0.075 \mathrm{M})$, the film density is also increased by 


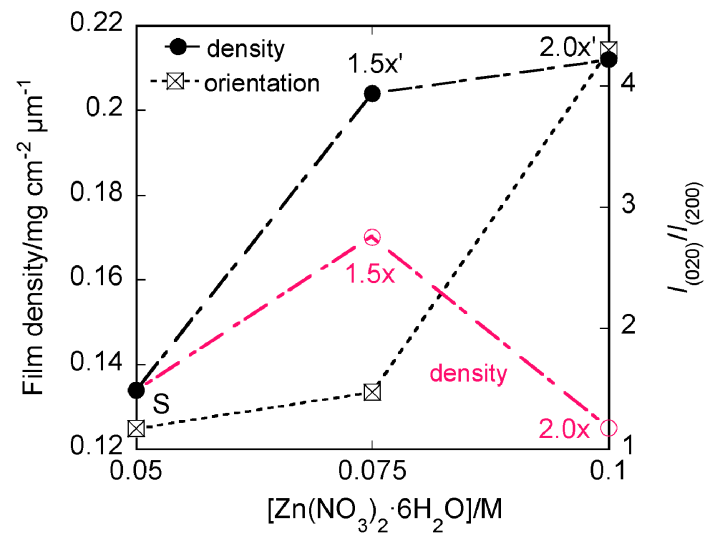

Fig. 5. The dependence of the film density and the degree of the $b$-axis orientation $\left(I_{(020)} / I_{(200)}\right)$ on the $\mathrm{Zn}\left(\mathrm{NO}_{3}\right)_{2} \cdot 6 \mathrm{H}_{2} \mathrm{O}$ concentration of the $\mathrm{CBD}$ solution for Film-S, 1.5 $\mathrm{x}^{\prime}$, and $2.0 \mathrm{x}^{\prime}$. The density for Film-1.5x and 2.0x are also shown for comparison. The slide glass substrates were used here.

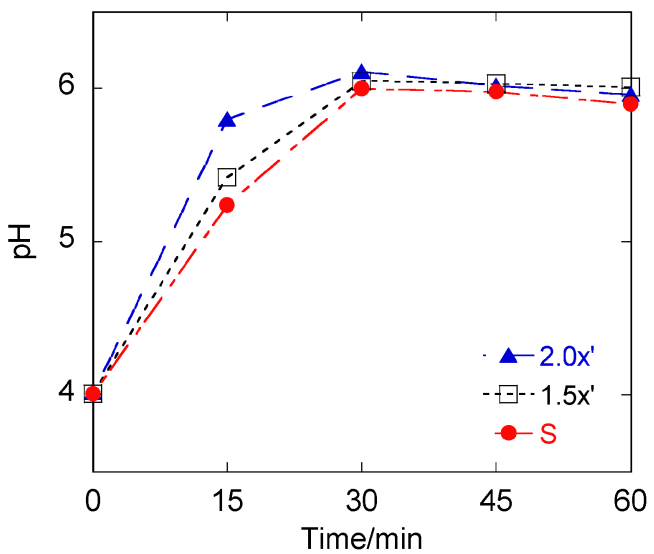

Fig. 6. The change of $\mathrm{pH}$ of the $\mathrm{CBD}$ solution with time for the standard to double the $\mathrm{Zn}\left(\mathrm{NO}_{3}\right)_{2} \cdot 6 \mathrm{H}_{2} \mathrm{O}$ and urea concentration.

increasing the urea concentration from $1.0 \mathrm{M}$ (Film-1.5x) to $1.5 \mathrm{M}$ (Film-1.5 $\mathrm{x}^{\prime}$ ).

Figure 6 shows the change of $\mathrm{pH}$ with the deposition time for the different concentrations. When the amount of urea is increased from 1.0 (Film-S) to $2.0 \mathrm{M}$ (Film-2.0 $\mathrm{x}^{\prime}$ ), there is a clear difference in the $\mathrm{pH}$ value at $15 \mathrm{~min}$. That is, the higher concentration of urea results in the higher $\mathrm{pH}$ value at $15 \mathrm{~min}$. As mentioned above, the film deposition was visibly confirmed at the time between 30 and $45 \mathrm{~min}$ for every concentration. It is then assumed that the higher increasing rate of $\mathrm{pH}$ accelerates the frequency of heterogeneous nucleation of LHZC at the earlier stage of the deposition. This effect can be seen on the increased density of Film-1.5 $\mathrm{x}^{\prime}$ and 2.0x' (see Fig. 5). However, a further increase of the concentrations led to the excess growth and hence the detachment of the deposited films (Film-3.0x' and 4.0x'). Consequently the deposition time had to be decreased from 6 to $4 \mathrm{~h}$ to obtain the appropriate precursor films.

\subsection{DSSC performance}

Figure 7 shows representative surface and cross-sectional FESEM images of the $\mathrm{ZnO}$ film converted from the LHZC film (Film-2.0 $\mathrm{x}^{\prime}$ ) on the slide glass substrate by heating at $400^{\circ} \mathrm{C}$ for $10 \mathrm{~min}$ in air. The morphology of the initial LHZC film (see Fig. 4) is successfully maintained in the $\mathrm{ZnO}$ film.

$J-V$ curves of DSSCs using the $\mathrm{ZnO}$ films derived from Film-
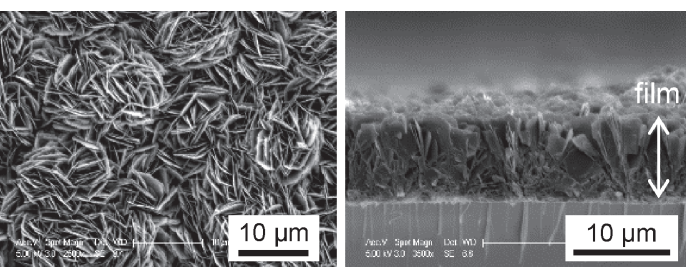

Fig. 7. Surface and cross-sectional FESEM images of the $\mathrm{ZnO}$ film converted from Film-2.0x $\mathrm{x}^{\prime}$ deposited on the slide glass substrate.

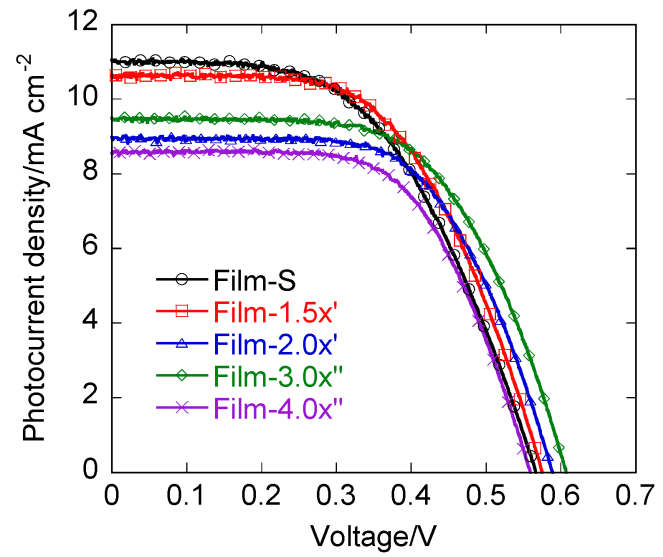

Fig. 8. $J-V$ curves of DSSCs using the $\mathrm{ZnO}$ films from Film-S, $1.5 \mathrm{x}^{\prime}$, $2.0 \mathrm{x}^{\prime}, 3.0 \mathrm{x}^{\prime \prime}$, and $4.0 \mathrm{x}^{\prime \prime}$ deposited on the FTO glass substrates.

Table 2. The cell parameters of the DSSCs using the $\mathrm{ZnO}$ films derived from the LHZC precursor films

\begin{tabular}{cccccc}
\hline Precursor film & $\begin{array}{c}V_{\mathrm{OC}} \\
/ \mathrm{V}\end{array}$ & $\begin{array}{c}J_{\mathrm{SC}} \\
/ \mathrm{mA} \mathrm{cm}^{-2}\end{array}$ & $f f$ & $\eta(\%)$ & $\begin{array}{c}\text { Dye amount } \\
/ 10^{-8} \mathrm{~mol} \mathrm{~cm}^{-2}\end{array}$ \\
\hline Film-S & 0.567 & 11.1 & 0.526 & 3.30 & 3.95 \\
Film-1.5x' & 0.575 & 10.6 & 0.569 & 3.48 & 4.04 \\
Film-2.0x' & 0.589 & 8.99 & 0.615 & 3.26 & 4.59 \\
Film-3.0x ${ }^{\prime \prime}$ & 0.607 & 9.48 & 0.606 & 3.49 & 4.92 \\
Film-4.0x ${ }^{\prime \prime}$ & 0.559 & 8.57 & 0.622 & 2.98 & 5.00 \\
\hline
\end{tabular}

$\mathrm{S}, 1.5 \mathrm{x}^{\prime}, 2.0 \mathrm{x}^{\prime}, 3.0 \mathrm{x}^{\prime \prime}$, and $4.0 \mathrm{x}^{\prime \prime}$ deposited on the FTO glass substrates are shown in Fig. 8. Also, DSSC parameters $\left(V_{\mathrm{OC}}, J_{\mathrm{SC}}\right.$, $f f$, and $\eta$ ) and the amount of adsorbed dyes are summarized in Table 2. It is noteworthy that the amount of dyes increases monotonically for the $\mathrm{ZnO}$ films from Film-S to $4.0 \mathrm{x}^{\prime \prime}$. This result seems to reflect the increase in the film density. The $f f$ values show a similar tendency. Although the $f f$ values are influenced by a large variety of factors, they are closely related to the total series resistance of the cell. For example, the dyesensitized semiconducting layers composed of $\mathrm{TiO}_{2}$ nanoparticles exhibit lower ff than those composed of $\mathrm{TiO}_{2}$ nanorods. ${ }^{14)}$ The film density therefore contributes to the effective transport of electrons in the cells with the present $\mathrm{ZnO}$ films.

The ideal $V_{\mathrm{OC}}$ value of DSSCs is defined as the difference between the quasi-Fermi level of the semiconductor and the redox potential. Actually, however, $V_{\mathrm{OC}}$ is changed by the interaction between the semiconductors and the redox electrolytes. ${ }^{15), 16)}$ Recombination of the electrons, which are injected from the excited dyes, with oxidized dyes in the electrolyte is the most important factor affecting the $V_{\mathrm{OC}}$ value. ${ }^{17)}$ The suppression of recombination usually leads to the increase in $V_{\mathrm{OC}}$. In the present case, $V_{\mathrm{OC}}$ is increased with increasing the film density for the $\mathrm{ZnO}$ 
films from Film-S to $3.0 \mathrm{x}^{\prime \prime}$, which is also related to the better electron transport as mentioned above. For Film-4.0x" , the partial detachment of the film led to the lower cell performance than the other films.

From our previous works, ${ }^{6-8)}$ the improvement of $V_{\mathrm{OC}}$ and $f f$ was a task when applying the LHZC-derived $\mathrm{ZnO}$ films to $\mathrm{DSSCs}^{8)}$ since $V_{\mathrm{OC}}(=0.56 \mathrm{~V})$ and $f f(=0.44)$ were not as high as those achieved in the case of LHZA $\left.{ }^{6}\right)\left(V_{\mathrm{OC}}=0.705 \mathrm{~V}\right.$ and $f f=0.534)$ or LHZN $\left(V_{\mathrm{OC}}=0.707 \mathrm{~V}\right.$ and $\left.f f=0.652\right){ }^{7}{ }^{7}$ The data shown in Table 2 demonstrate that $V_{\mathrm{OC}}$ and $f f$ have been improved in the LHZC-derived $\mathrm{ZnO}$ films as compared to our previous data. ${ }^{8)}$ It should also be mentioned that a large difference in the morphology of the $\mathrm{ZnO}$ films derived from LHZA, LHZN, and LHZC produces characteristic cell performance for each DSSC: each average cell parameter for LHZA (with a flower-like or a cabbage-like morphology), high $V_{\mathrm{OC}}$ and $f f$ for LHZN (with an entangled sheet-like morphology), and high $J_{\mathrm{SC}}$ for LHZC (wih the accumulated sheet-like morphology). In Table 2, however, $J_{\mathrm{SC}}$ of the cells using the present LHZCderived $\mathrm{ZnO}$ films remained low as compared to the previous work $\left(J_{\mathrm{SC}}=13.8 \mathrm{~mA} \mathrm{~cm}^{-2}\right)$. Tentatively we consider that the lowered $J_{\mathrm{SC}}$ is attributed to the aggregation of dyes and/or the suppression of the diffusion of the electrolyte in the denser films. In the future work, the heating condition of the LHZC films and the dye loading condition of the $\mathrm{ZnO}$ films will be optimized according to the change of the microstructural characteristics.

The conversion efficiency $(\eta)$ is defined as the product of $V_{\mathrm{OC}}$, $J_{\mathrm{SC}}$, and $f f$, divided by the incident light power $\left(P_{\mathrm{in}}\right) ; \eta=V_{\mathrm{OC}} \times$ $J_{\mathrm{SC}} \times f f / P_{\text {in. }}$. It is therefore less meaningful to compare closely the efficiency of each cell, especially in the case where all of $V_{\mathrm{OC}}$, $J_{\mathrm{SC}}$, and $f f$ are changing. At least it can be said that the DSSCs using the LHZC-derived $\mathrm{ZnO}$ films have the capability of showing the efficiencies more than $3 \%$.

\section{Conclusions}

$\mathrm{ZnO}$ nanosheet-accumulated films were obtained via LHZC precursor films which were deposited in the aqueous solutions. The degree of the $b$-axis orientation and the film density had a good correlation among the LHZC films from the concentrationcontrolled solutions. It was conceivable that the above characteristics were subject to the number of nuclei formed on the substrates through heterogeneous nucleation at the initial stage of the deposition. The change in the film density of the LHZC films was taken over by the $\mathrm{ZnO}$ films used as photoanodes in DSSCs. A similar trend was clearly observed in the film density and the cell performance especially for $V_{\mathrm{OC}}$ and $f f$. The improved $V_{\mathrm{OC}}$ and ff gave the conversion efficiency of $3.49 \%$ in the present work.

\section{References}

1) T. P. Chou, Q. Zhang and G. Cau, J. Phys. Chem. C, 111, 18804-18811 (2007).

2) M. Law, L. E. Greene, J. C. Johnson, R. Saykally and P. D. Yang, Nat. Mater., 4, 455-459 (2005).

3) A. E. Suliman, Y. W. Tang and L. Xu, Sol. Energy Mater. Sol. Cells, 91, 1658-1662 (2007).

4) C. F. Lin, H. Lin, J. B. Li and X. Li, J. Alloys Compd., 462, 175-180 (2008).

5) J. B. Baxter and E. S. Aydil, Sol. Energy Mater. Sol. Cells, 90, 607-622 (2006).

6) S. Ueno and S. Fujihara, J. Electrochem. Soc., 158, K1-K5 (2011).

7) T. Yuki, S. Ueno, M. Hagiwara and S. Fujihara, J. Asian Ceram. Soc., 3, 144-150 (2015).

8) K. Kakiuchi, M. Saito and S. Fujihara, Thin Solid Films, 516, 2026-2030 (2008).

9) B. C. Bunker, P. C. Rieke, B. J. Tarasevich, A. A. Campbell, G. E. Fryxell, G. L. Graff, L. Song, J. Liu, J. W. Virden and G. L. McVay, Science, 264, 48-55 (1994).

10) K. Govender, D. S. Boyle, P. B. Kenway and P. O'Brien, J. Mater. Chem., 14, 2575-2591 (2004).

11) E. Hosono, S. Fujihara, I. Honma and H. Zhou, Adv. Mater, 17, 2091-2094 (2005).

12) K. M. Udert, T. A. Larsen, M. Biebow and W. Guijer, Water Res., 37, 2571-2582 (2003).

13) J. Chang, M. Z. Ahmad, W. Wlodarski and E. R. Waclawik, Sensors (Basel Switzerland), 13, 8445-8460 (2013).

14) J. Jiu, S. Isoda, F. Wang and M. Adachi, J. Phys. Chem. B, 110, 2087-2092 (2006).

15) S. Y. Huang, G. Schlichthörl, A. J. Nozik, M. Grätzel and A. J. Frank, J. Phys. Chem. B, 101, 2576-2582 (1997).

16) T. Le Bahers, F. Labat, T. Pauporté and I. Ciofini, Phys. Chem. Chem. Phys., 12, 14710-14719 (2010).

17) M. K. Nazeeruddin, A. Kay, I. Rodicio, R. Humphry-Baker, E. Müller, P. Liska, N. Vlachopoulos and M. Grätzel, J. Am. Chem. Soc., 115, 6382-6390 (1993). 